Caroline M.J. van Kinschot*, Robin P. Peeters, Sjoerd A.A. van den Berg, Frederik A. Verburg, Charlotte van Noord, Tessa M. van Ginhoven and W. Edward Visser

\title{
Thyroglobulin and thyroglobulin antibodies: assay-dependent management consequences in patients with differentiated thyroid carcinoma
}

https://doi.org/10.1515/cclm-2021-1046

Received September 26, 2021; accepted January 14, 2022;

published online January 28, 2022

\section{Abstract}

Objectives: International guidelines recommend fixed cut-off values for thyroglobulin (Tg). These cut-offs do not take potential assay differences into account. This study aimed to evaluate if different assays for $\mathrm{Tg}$ and $\mathrm{Tg}$ antibodies (TgAb) affect management guidance for differentiated thyroid cancer (DTC) patients.

Methods: In 793 samples derived from 413 patients with DTC, Tg and TgAb were simultaneously measured with two immunometric assays: Immulite 2000XPi and Kryptor compact plus. In addition, a qualitative measurement for $\mathrm{TgAb}$ interference (recovery test) was performed on the Kryptor compact plus platform. The extent to which different assays lead to different classifications of response to therapy was evaluated when applying the current cut-offs for $\mathrm{Tg}$. Results: Mean Tg concentrations were $37.4 \%$ lower with Kryptor as compared with Immulite. Applying guideline based cut-off values for Tg, 33 (4.7\%) samples had a Tg-on concentration $\geq 1.0 \mu \mathrm{g} / \mathrm{L}$ with Immulite and $<1.0 \mu \mathrm{g} / \mathrm{L}$ with Kryptor. Of the samples tested as $\mathrm{TgAb}+$ with at least one assay ( $\mathrm{n}=125), 68$ (54.4\%) samples showed discrepancy in $\mathrm{TgAb}$ status. Differences between Immulite and Kryptor measurements resulted in a change in the response to therapy classification in $94(12.0 \%)$ measurements derived from 67 (16.2\%) individual patients.

Conclusions: A substantial portion of DTC patients were classified differently dependent on which $\mathrm{Tg}$ and $\mathrm{TgAb}$ assays are used, when applying the cut-off values as defined in clinical guidelines. Such differences can significantly affect clinical management. In the context of large between-method variation, the recommended Tg cutoffs in guidelines should be used with wisdom rather than as fixed cut-offs.

Keywords: differentiated thyroid cancer (DTC); guideline cut-offs; immunometric assay; response to therapy classification; thyroglobulin (Tg); thyroglobulin antibodies (TgAb).

\section{Introduction}

*Corresponding author: Caroline M.J. van Kinschot, MD, Academic Center for Thyroid Diseases, Department of Internal Medicine, Erasmus Medical Center, Doctor Molewaterplein 40, 3015 GD, Rotterdam, The Netherlands; and Department of Internal Medicine, Maasstad Hospital, Rotterdam, The Netherlands,

E-mail: c.vankinschot@erasmusmc.nl.https://orcid.org/0000-00020520-7698

Robin P. Peeters and W. Edward Visser, Academic Center for Thyroid Diseases, Department of Internal Medicine, Erasmus Medical Center, Rotterdam, The Netherlands

Sjoerd A.A. van den Berg, Academic Center for Thyroid Diseases, Department of Internal Medicine, Erasmus Medical Center, Rotterdam, The Netherlands; and Department of Clinical Chemistry, Erasmus Medical Center, Rotterdam, The Netherlands

Frederik A. Verburg, Department of Nuclear Medicine, Erasmus Medical Center, Rotterdam, The Netherlands

Charlotte van Noord, Department of Internal Medicine, Maasstad Hospital, Rotterdam, The Netherlands

Tessa M. van Ginhoven, Academic Center for Thyroid Diseases, Department of Surgery, Erasmus Medical Center, Rotterdam, The Netherlands
Measurement of serum thyroglobulin (Tg) has an essential role in follow-up monitoring of patients with differentiated thyroid cancer (DTC). Tg measurements in combination with a neck ultrasound have a high sensitivity for detecting persistent or recurrent disease in patients previously treated with thyroidectomy and radioactive iodine (RAI) ablation [1].

Currently, most laboratories have adopted an automated immunometric assay for measurement of Tg. In recent years the diagnostic sensitivity has been improved with the introduction of assays with functional sensitivities (FS) $\leq 0.1 \mu \mathrm{g} / \mathrm{L}$, also referred to as high-sensitive Tg assays (hs-Tg).

The measurement of $\mathrm{Tg}$ is complicated by multiple factors. First, a large between-method variation regarding sensitivity, accuracy and precision prevents comparison of (consecutive) Tg measurements with different assays [2-4]. 
Second, Tg assays suffer from interfering endogenous $\mathrm{Tg}$ antibodies (TgAb), which are detected in up to $20 \%$ of patients with DTC [2]. As for Tg, immunometric assays for $\operatorname{TgAb}$ also show large between-method variation, which impedes the correct identification of patients with interfering $\operatorname{Tg} A b[5-7]$.

International guidelines state fixed cut-offs for $\mathrm{Tg}$; $<0.2 \mu \mathrm{g} / \mathrm{L}$ and $<1.0 \mu \mathrm{g} / \mathrm{L}$ for thyrotropin (TSH) suppressed measurements (Tg-on) and $<1.0 \mu \mathrm{g} / \mathrm{L}$ and $<10.0 \mu \mathrm{g} / \mathrm{L}$ for recombinant human TSH (rh-TSH) stimulated Tg measurements $[8,9]$. Prognostic predictions and recommendations on the frequency of follow-up, additional investigations and continuation of TSH suppressive therapy are based on these cut-offs which are derived from studies using a variety of $\mathrm{Tg}$ and $\mathrm{TgAb}$ assays [10-14].

This study aimed to evaluate to what extent different methods for Tg and TgAb measurement affect management guidance for individual DTC patients. Therefore, in a large cohort of DTC patients, Tg and TgAb were measured simultaneously with Immulite 2000XPi and Kryptor compact plus, both immunometric assays, and related to clinical disease status.

\section{Materials and methods}

\section{Selection of patients}

This study was performed at the Erasmus University Medical Center, Rotterdam, The Netherlands, a regional referral center for thyroid cancer. Samples for Tg and TgAb measurements were taken from DTC patients who had a follow-up visit between January 2018 and April 2019. All patients had been treated with a total thyroidectomy and RAI ablation. Follow-up was in accordance with national guideline recommendations (see Supplementary Methods). Tg-on, rh-TSH-Tg and $\mathrm{Tg}$ after withdrawal for radioiodine treatment (Tg-off) were included in the analysis. Measurements taken within the first six months after RAI ablation were excluded, as were samples from patients with tumors containing areas of poor differentiation. Clinical data were retrieved from medical records. At time of Tg measurement the response to therapy was assessed according to the classification proposed in the 2015 American Thyroid Association (ATA) Guideline [8]. Patients were considered to have an excellent response to therapy if Tg-on was $<0.2 \mu \mathrm{g} / \mathrm{L}$ or rh-TSH-Tg was $<1 \mu \mathrm{g} / \mathrm{L}$ in combination with negative imaging and undetectable TgAb. In case of Tg-on $\geq 1 \mu \mathrm{g} / \mathrm{L}$, rhTSH$\mathrm{Tg} \geq 10 \mu \mathrm{g} / \mathrm{L}$ or rising $\mathrm{TgAb}$ concentrations, a patient was classified as having a biochemical incomplete response. Patients with structural or functional evidence of disease were classified as structural incomplete response. Finally, patients with one of the following: Tg-on $>0.2 \mu \mathrm{g} / \mathrm{L}$ but $<1 \mu \mathrm{g} / \mathrm{L}$ or rh-TSH-Tg $>1.0 \mu \mathrm{g} / \mathrm{L}$ but $<10 \mu \mathrm{g} / \mathrm{L}$, nonspecific findings on imaging studies, stable or declining $\mathrm{TgAb}$, were considered to have an indeterminate response. Measurements with Tg-on levels $>1.0 \mu \mathrm{g} / \mathrm{L}$ in combination with $\mathrm{TgAb}$ above the cut-off value were considered as biochemical disease.
Existing criteria for disease classifications were tailored to allow for comparison between assays. Patients with a Kryptor Tg-on between $0.15 \mu \mathrm{g} / \mathrm{L}$ and $1.0 \mu \mathrm{g} / \mathrm{L}$ in the absence of a Kryptor rh-TSH-Tg measurement were categorized as having an indeterminate response, irrespective of Immulite rh-TSH-Tg measurements performed before the study period. In the absence of an rh-TSH-Tg measurement, patients were classified as having an excellent response if follow-up since diagnosis has lasted for more than 10 years without detectable $\mathrm{Tg}$-on or radiological signs of recurrent disease. If the assessment of the response to therapy had not yet been performed at all (e.g., after additional treatment for recurrent disease) the disease status was indicated as "not yet stratified". This study was approved by the medical Ethical Board of the Erasmus University Medical Center (MEC-2018-1195).

\section{Laboratory procedures}

Tg assays: Serum Tg was measured with two immunometric assays: Immulite 2000XPi (Siemens Healthcare Diagnostics Inc, Tarrytown, NY, USA) and Kryptor compact plus (B.R.A.H.M.S Thermo Fischer Scientific, Hennigsdorf, Germany), according to manufacturers' instructions. Both Tg assays have been standardized against the same Tg reference material (CRM 457). The functional sensitivity for Tg measurement (defined as an interassay coefficient of variation of $20 \%$ ) as provided by the manufacturer is $0.9 \mu \mathrm{g} / \mathrm{L}$ for Immulite and $0.15 \mu \mathrm{g} / \mathrm{L}$ for Kryptor, both verified in an ISO15189 accredited laboratory. Verification performed in our laboratory showed a negative analytical bias for the Kryptor assay of 35\% (Supplementary Figure S1). Additionally, an institutional cut-off was established for the Kryptor Tg assay in a subset of 55 patients with both basal Tg-on and rh-TSH-Tg measurements available. The optimum cut-off for Kryptor Tg-on was found to be $0.15 \mu \mathrm{g} / \mathrm{L}$, which is similar to the functional sensitivity as defined by the manufacturer (see Supplementary Text and Supplementary Figure S2). For the purpose of comparing mean concentrations between Immulite and Kryptor, undetectable Tg concentrations were plotted as 0.0.

TgAb assays and recovery analysis: $\mathrm{TgAb}$ were measured with assays from the same manufacturers as the $\mathrm{Tg}$ assays. Both $\mathrm{TgAb}$ assay have been standardized against the international reference preparation (MRC 65/93).

For the Kryptor TgAb assay a cut-off of $33 \mathrm{U} / \mathrm{mL}$ was used, corresponding to the functional sensitivity (Thermofisher instructions for use). For the Immulite TgAb assay the functional sensitivity was not provided by the manufacturer. An institutional cut-off of $9 \mathrm{U} / \mathrm{mL}$ was defined above which a clinically relevant interference with Tg measurement of at least $80 \%$ was measured. The cut-off of $9 \mathrm{U} / \mathrm{mL}$ is compatible with the upper reference limit for the Immulite TgAb assay as established in healthy individuals according to the National Academy of Clinical Biochemistry guidelines [15]. A Tg recovery test was performed on the Kryptor platform. An automatically adapted Tg concentration was added to the serum, based on the native Tg concentration. If the native $\mathrm{Tg}$ concentration was $<5 \mu \mathrm{g} / \mathrm{L}$, the $\mathrm{Tg}$ concentration of the added solution was $2.5 \mu \mathrm{g} / \mathrm{L}$. If the native $\mathrm{Tg}$ concentration exceeded $5 \mu \mathrm{g} / \mathrm{L}$, the concentration of the added solution was $20 \mu \mathrm{g} / \mathrm{L}$. According to the manufacturers' instructions a recovery between 80 and $120 \%$ was considered as undisturbed. 


\section{Statistical analysis}

The non-parametric Mann-Whitney test was used for testing associations. Statistical analysis were performed using Statistical Package for the Social Sciences (SPSS) (IBM Corp. Released 2017. IBM SPSS Statistics for Windows, Version 25.0. Armonk, NY: IBM Corp). Deming regression analyses were performed using Evaluation Protocol (EP) Evaluator 12.0 (2017, South Burlington, VT).

\section{Results}

\section{Comparison of assays}

A total number of 793 samples, derived from 413 DTC patients, were analyzed for $\mathrm{Tg}$ and $\mathrm{TgAb}$. The majority of patients (80.6\%) had papillary thyroid cancer (PTC). In 184 (44.6\%) patients, a single $\mathrm{Tg} / \mathrm{TgAb}$ measurement was performed, in 137 (33.2\%) patients two measurements were performed and in 92 patients $(22.3 \%)$ three or more measurements. The cohort comprised 702 (88.5\%) Tg-on measurements, $71(9.0 \%)$ rh-TSH-Tg measurements and 20 (2.5\%) Tg-off measurements (Table 1).

$\mathrm{Tg}$ was measurable in 270 (34.0\%) samples with Immulite and in 595 (75.0\%) with Kryptor. Mean Tg concentrations were $37.4 \%$ lower with Kryptor (mean $39.5 \mu \mathrm{g} / \mathrm{L}$ ) compared with Immulite (mean $63.1 \mu \mathrm{g} / \mathrm{L}$ ). The betweenmethod correlation coefficient was 0.985 (Figure 1A).

In $80(20.2 \%)$ and $102(24.3 \%)$ samples, TgAb were tested as positive with Immulite and Kryptor, respectively. These samples were derived from 34 (8.2\%) and 56 (13.5\%) individual patients, respectively. The between-method correlation coefficient was 0.6155 (Figure 1B).

Median Tg concentrations were significantly higher in $\mathrm{TgAb}$ - measurements compared with $\mathrm{TgAb}+$ measurements (Table 2).

\section{Impact on clinical practice}

Applying guideline based cut-off values, 33 (4.7\%) samples in $25(6 \%)$ patients had a Tg-on concentration $\geq 1.0 \mu \mathrm{g} / \mathrm{L}$ with Immulite and $<1.0 \mu \mathrm{g} / \mathrm{L}$ with Kryptor (Figure 2). In rhTSH-Tg measurements, 3 (4.3\%) measurements in three individual patients, showed discrepancy with regard to the cut-off of $1.0 \mu \mathrm{g} / \mathrm{L}$ : Tg measured with Immulite was above the cut-off and with Kryptor below the cut-off of $1.0 \mu \mathrm{g} / \mathrm{L}$. No discrepancy between the assays was observed for the cut-off of $10 \mu \mathrm{g} / \mathrm{L}$. Of the samples determined as TgAb+ with at least one assay ( $\mathrm{n}=125), 68$ (54.4\%) samples, derived from $47(11.4 \%)$ individual patients, showed discrepancy in $\mathrm{TgAb}$ positivity between either assay.
Table 1: Patient and measurement characteristics.

\begin{tabular}{lr}
\hline Patients (n=413) & $\mathbf{n}(\%)$ \\
\hline Sex & \\
Female & $287(69.5 \%)$ \\
Male & $126(30.5 \%)$ \\
Age, years & \\
$\quad$ At first measurement & $52.4 \pm 15.5$ \\
& $(18.5-88.8)$ \\
Histology & \\
PTC & $333(80.6 \%)$ \\
FTC & $59(14.3 \%)$ \\
HCC & $7(1.7 \%)$ \\
FVPTC & $9(2.2 \%)$ \\
Other & $5(1.2 \%)$ \\
Metastatic disease & $76(18.4 \%)$ \\
Only localized in the neck & $31(7.5 \%)$ \\
Distant metastases & $45(10.9 \%)$ \\
Number of measurements per individual & \\
patient & \\
1 & $184(44.6 \%)$ \\
2 & $137(33.2 \%)$ \\
$\geq 3$ (maximum nine) & $92(22.3 \%)$ \\
\hline Measurements (n=793) & $71(9.0 \%)$ \\
\hline Type of Tg measurement & $20(2.5 \%)$ \\
Thyrotropin suppressed (Tg-on) & \\
Recombinant human TSH stimulated & \\
(rh-TSH-Tg) & \\
After withdrawal of levothyroxin (Tg-off) & \\
\hline & \\
\hline
\end{tabular}

Tg, thyroglobulin; TgAb, Tg antibodies; PTC, papillary thyroid cancer; FTC, follicular thyroid cancer; HCC, hurthle cell carcinoma; FVPTC, follicular variant of papillary thyroid carcinoma.

Using either assay, the response to therapy classification was influenced in 94 (12.0\%) measurements, derived from $67(16.2 \%)$ individual patients. The Kryptor assay resulted in a larger number of measurements fitting the indeterminate response category, 177 (22.3\%) with Kryptor vs. 134 (16.9\%) with Immulite. The number of measurements categorized as excellent response decreased from 302 (38.1\%) with Immulite to 276 (34.8\%) with Kryptor (Figure 3). In 159 (33.8\%) measurements with an Immulite $\mathrm{Tg}<1.0 \mu \mathrm{g} / \mathrm{L}$ the $\mathrm{Tg}$ concentration measured with Kryptor was between 0.2 and $1.0 \mu \mathrm{g} / \mathrm{L}$. In $47(30 \%)$ of these measurements, derived from 39 (9.4\%) individual patients, a previous Immulite rh-TSH-Tg had qualified these patients as having an excellent response.

\section{Recovery}

In 675 samples (85.1\%) a Kryptor recovery measurement was performed in addition to the quantitative $\mathrm{TgAb}$ 

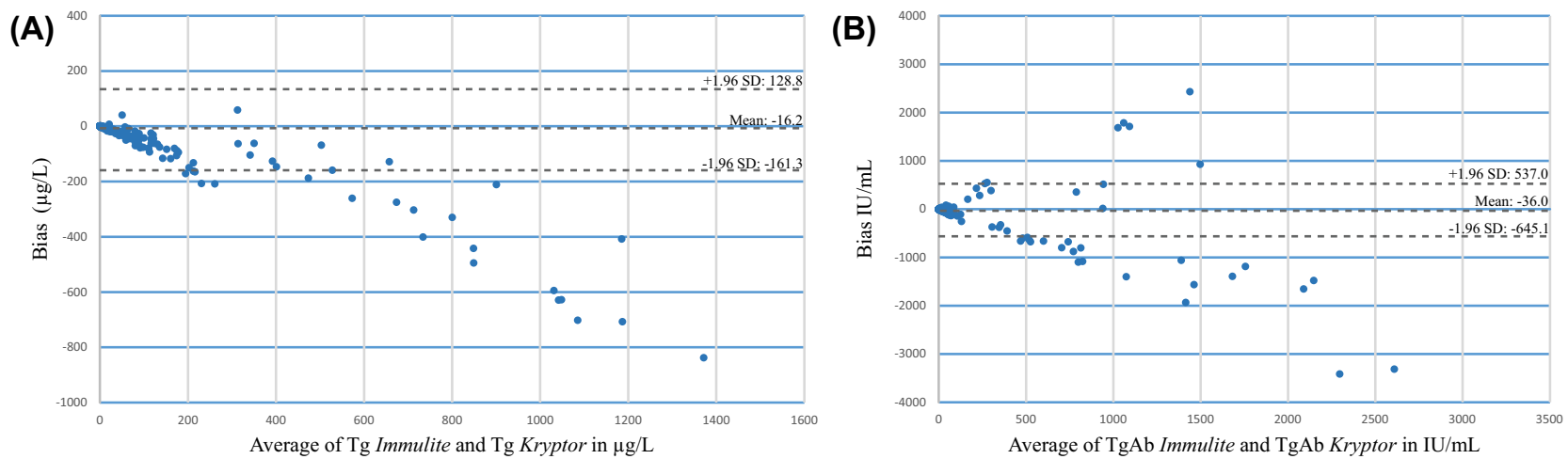

Figure 1: Bland-Altman plot of agreement between Immulite and Kryptor for Tg (A) en TgAb (B). Outliers ( $\mathrm{n}=3$ ) were excluded.

Table 2: $\operatorname{Tg}(\mu \mathrm{g} / \mathrm{L})$ in $\operatorname{TgAb}$ positive and $\operatorname{TgAb}$ negative patients.

\begin{tabular}{|c|c|c|c|c|c|c|c|c|c|c|}
\hline & \multicolumn{4}{|c|}{ Immulite } & \multirow{3}{*}{$\begin{array}{r}\text { Mann-Whitney } \\
\text { U (p-value) }\end{array}$} & \multicolumn{4}{|c|}{ Kryptor } & \multirow{3}{*}{$\begin{array}{r}\text { Mann-Whitney } \\
\text { U (p-value) }\end{array}$} \\
\hline & \multicolumn{2}{|c|}{$\begin{array}{l}\text { TgAb positive } \\
\text { (>9 U/mL) }\end{array}$} & \multicolumn{2}{|c|}{$\begin{array}{l}\text { TgAb negative } \\
\text { (<9 U/mL) }\end{array}$} & & \multicolumn{2}{|c|}{$\begin{array}{l}\text { TgAb positive } \\
\text { (>33 U/mL) }\end{array}$} & \multicolumn{2}{|c|}{$\begin{array}{l}\text { TgAb negative } \\
\text { (<33 U/mL) }\end{array}$} & \\
\hline & $\mathbf{n}$ & Median (IQR) & $\mathbf{n}$ & Median (IQR) & & $\mathbf{n}$ & Median (IQR) & $\mathbf{n}$ & Median (IQR) & \\
\hline \multicolumn{11}{|c|}{ All measurements } \\
\hline $\begin{array}{l}\mathrm{Tg} \\
\text { Immulite }\end{array}$ & 80 & $\begin{array}{r}<0.9 \\
(<0.9-<0.9)\end{array}$ & 713 & $\begin{array}{r}<0.9 \\
(<0.9-3.65)\end{array}$ & 0.004 & 102 & $\begin{array}{r}<0.9 \\
(<0.9-<0.9)\end{array}$ & 691 & $\begin{array}{r}<0.9 \\
(<0.9-3.60)\end{array}$ & 0.042 \\
\hline Tg Kryptor & 80 & $\begin{array}{r}<0.1 \\
(<0.1-0.47)\end{array}$ & 713 & $0.2(<0.1-2.16)$ & $<0.0001$ & 102 & $\begin{array}{r}0.1 \\
(<0.1-0.74)\end{array}$ & 691 & $\begin{array}{r}0.2 \\
(0.10-2.00)\end{array}$ & 0.0004 \\
\hline \multicolumn{11}{|c|}{ Biochemical disease $^{a}$} \\
\hline $\begin{array}{l}\mathrm{Tg} \\
\text { Immulite }\end{array}$ & 7 & $\begin{array}{r}<0.9 \\
(<0.9-<0.9)\end{array}$ & 74 & $\begin{array}{r}4.6 \\
(1.78-24.88)\end{array}$ & 0.0002 & 8 & $\begin{array}{r}<0.9 \\
(<0.9-0.75)\end{array}$ & 73 & $\begin{array}{r}4.6 \\
(1.80-28.25)\end{array}$ & $<0.0001$ \\
\hline Tg Kryptor & 7 & $\begin{array}{r}0.1 \\
(<0.1-0.16)\end{array}$ & 74 & $\begin{array}{r}2.8 \\
(1.10-13.63)\end{array}$ & 0.0002 & 8 & $\begin{array}{r}0.1 \\
(<0.1-0.71)\end{array}$ & 73 & $\begin{array}{r}2.8 \\
(1.10-14.35)\end{array}$ & 0.0002 \\
\hline \multicolumn{11}{|c|}{ Structural disease $\mathrm{e}^{\mathrm{a}}$} \\
\hline $\begin{array}{l}\mathrm{Tg} \\
\text { Immulite }\end{array}$ & 23 & $\begin{array}{r}10.0 \\
(<0.9-218.0)\end{array}$ & 190 & $\begin{array}{r}22.6 \\
(1.67-90.13)\end{array}$ & 0.374 & 30 & $\begin{array}{r}94.6 \\
(<0.9-605.50)\end{array}$ & 183 & $\begin{array}{r}21.1 \\
(1.60-83.10)\end{array}$ & 0.419 \\
\hline Tg Kryptor & 23 & $\begin{array}{r}6.0 \\
(0.10-130.2)\end{array}$ & 190 & $\begin{array}{r}12.2 \\
(0.92-54.00)\end{array}$ & 0.531 & 30 & $\begin{array}{r}63.3 \\
(0.10-485.65)\end{array}$ & 183 & $\begin{array}{r}10.8 \\
(0.90-52.10)\end{array}$ & 0.448 \\
\hline \multicolumn{11}{|c|}{ Normal recovery } \\
\hline $\begin{array}{l}\mathrm{Tg} \\
\text { Immulite }\end{array}$ & 45 & $\begin{array}{r}<0.9 \\
(<0.9-<0.9)\end{array}$ & 568 & $\begin{array}{r}<0.9 \\
(<0.9-2.68)\end{array}$ & 0.067 & 71 & $\begin{array}{r}<0.9 \\
(<0.9-<0.9)\end{array}$ & 542 & $\begin{array}{r}<0.9 \\
(<0.9-2.73)\end{array}$ & 0.173 \\
\hline Tg Kryptor & 45 & $\begin{array}{r}<0.1 \\
(<0.1-0.71)\end{array}$ & 568 & $\begin{array}{r}0.2 \\
(0.10-1.40)\end{array}$ & 0.002 & 71 & $\begin{array}{r}0.1 \\
(<0.10-0.80)\end{array}$ & 542 & $\begin{array}{r}0.2 \\
(0.10-1.40)\end{array}$ & 0.031 \\
\hline
\end{tabular}

${ }^{a}$ Disease status based on Tg measurements with Immulite. Tg, thyroglobulin; TgAb, Tg antibodies. p-Values $<0.05$ are given in bold.

measurement. Overall, median recovery values were significantly lower in $\mathrm{TgAb}+$ samples compared to $\mathrm{TgAb}-$ samples (Table 3). In Immulite $\mathrm{TgAb}+$ samples the median recovery was $95.0 \%$ (range $55.0-145.0 \%$ ) vs. $105.0 \%$ (range 52.0-152.0\%) in Immulite TgAb- samples. In Kryptor $\mathrm{TgAb}+$ samples the median recovery was $101.5 \%$ (range $55.0-145.0 \%$ ) vs. $105.0 \%$ (range $52.0-152.0 \%$ ) in Kryptor TgAb- samples.

A disturbed recovery with a percentage of less than $80 \%$ was observed in only $18(2.6 \%)$ samples. Of those 18 samples, 14 (77.8\%) samples showed TgAb positivity with both the Kryptor and Immulite TgAb assays, 3 (16.7\%) samples only positivity with Immulite and one (5.6\%) sample was considered $\mathrm{TgAb}$ negative with both assays.

A disturbed recovery with a percentage above $120 \%$ was observed in 44 (5.5\%) samples, derived from 37 patients. In $6(13.6 \%)$ of these samples TgAb were tested as positive with one or both assays.

In the subset of measurements with a normal recovery value (80-120\%) median Kryptor Tg was significantly 


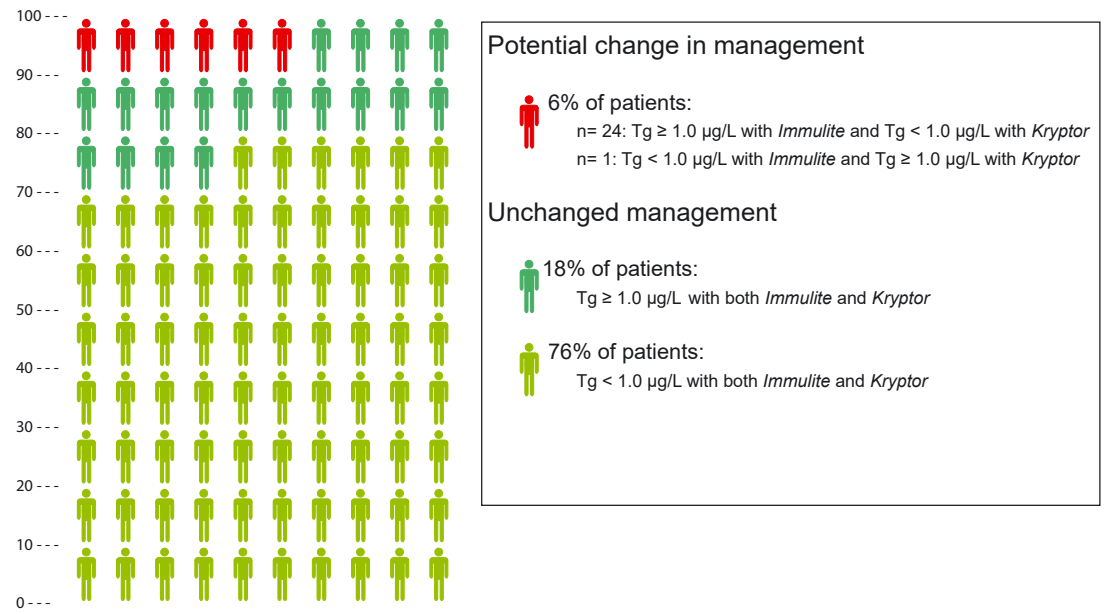

Figure 2: Icon array showing the percentage of patients with discordant Tg results when applying a cut-off $1.0 \mu \mathrm{g} / \mathrm{L}$ in Tg-on measurements.

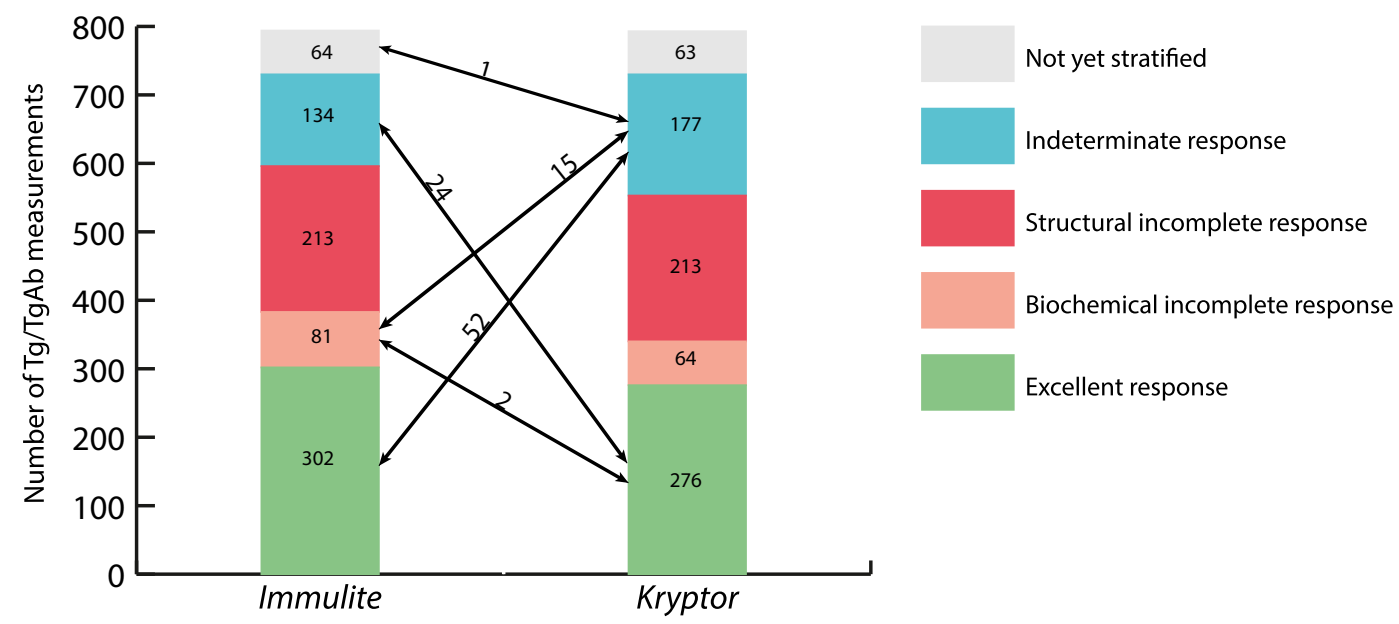

Figure 3: Discordance in response to therapy classification.

For each Tg/TgAb measurement the response to therapy at time of measurements was assessed according to the classification in the 2015 ATA Management Guidelines for adult patients with thyroid nodules and differentiated thyroid cancer. For the purpose of analysis some adjustments were made as described in the method section. Discordance was observed in 94 measurements (12.0\%) derived from 67 (16.5\%) individual patients.

higher in the $\mathrm{TgAb}$ - group compared to the $\mathrm{TgAb}+$ group, whereas median Immulite $\mathrm{Tg}$ did not significantly differ between TgAb+ and TgAb- groups (Table 2).

\section{Loco regional or distant metastases}

In 21 out of 76 patients (27.6\%) with structural disease, $\mathrm{Tg}$ on was undetectable with one or both assays. For 15 patients recovery analysis was available and ranged from
$75 \%$ to $125 \%$ (Table 4). Although Immulite failed to detect $\mathrm{Tg}$ in all these patients, Kryptor detected Tg in 12 out of 15 patients.

\section{Discussion}

This study evaluated the impact of guideline recommended Tg cut-offs in clinical management of DTC in a cohort of 413 DTC patients. The data show that, when applying these 
Table 3: Recovery (\%) in TgAb positive and TgAb negative patients.

\begin{tabular}{|c|c|c|c|c|c|c|c|c|c|c|}
\hline & \multicolumn{4}{|c|}{ Immulite } & \multirow{3}{*}{$\begin{array}{r}\text { Mann-Whitney } \\
\text { U (p-value) }\end{array}$} & \multicolumn{4}{|c|}{ Kryptor } & \multirow{3}{*}{$\begin{array}{r}\text { Mann-Whitney } \\
\text { U (p-value) }\end{array}$} \\
\hline & \multicolumn{2}{|c|}{$\begin{array}{c}\text { TgAb positive } \\
\text { (>9 U/mL) }\end{array}$} & \multicolumn{2}{|c|}{$\begin{array}{c}\text { TgAb negative } \\
\text { (<9 U/mL) }\end{array}$} & & \multicolumn{2}{|c|}{$\begin{array}{l}\text { TgAb positive } \\
\text { (>33 } \mathrm{U} / \mathrm{mL})\end{array}$} & \multicolumn{2}{|c|}{$\begin{array}{l}\text { TgAb negative } \\
\text { (<33 U/mL) }\end{array}$} & \\
\hline & n & Median (range) & $\mathbf{n}$ & Median (range) & & $\mathbf{n}$ & Median (range) & $\mathbf{n}$ & Median (range) & \\
\hline \multicolumn{11}{|c|}{ All measurements } \\
\hline Recovery & 65 & $\begin{array}{r}95.0 \\
(55.0-145.0)\end{array}$ & 610 & $\begin{array}{r}105.0 \\
(52.0-152.0)\end{array}$ & $<0.0001$ & 90 & $\begin{array}{r}101.5 \\
(55.0-145.0)\end{array}$ & 585 & $\begin{array}{r}105.0 \\
(52.0-152.0)\end{array}$ & $<0.0001$ \\
\hline \multicolumn{11}{|c|}{ Structural disease $^{\mathrm{a}}$} \\
\hline Recovery & 18 & $\begin{array}{r}102.0 \\
(67.0-145.0)\end{array}$ & 157 & $\begin{array}{r}110.0 \\
(92.0-152.0)\end{array}$ & 0.006 & 26 & $\begin{array}{r}104.0 \\
(67.0-145.0)\end{array}$ & 149 & $\begin{array}{r}110.0 \\
(88-152.0)\end{array}$ & 0.015 \\
\hline
\end{tabular}

${ }^{a}$ Disease status based on Tg measurements with Immulite. TgAb, Tg antibodies. p-Values $<0.05$ are given in bold.

Table 4: Patients with structural disease and undetectable Tg-on with either Immulite ( $<0.9 \mu \mathrm{g} / \mathrm{L})$ or Kryptor $(<0.1 \mu \mathrm{g} / \mathrm{L})$.

\begin{tabular}{|c|c|c|c|c|c|c|c|c|c|}
\hline \multirow[t]{2}{*}{ Patient } & \multirow[t]{2}{*}{ Sex } & \multirow[t]{2}{*}{ Age } & \multirow[t]{2}{*}{ Histology } & \multirow[t]{2}{*}{ Location of metastases } & \multicolumn{2}{|c|}{$\mathrm{Tg}, \mu \mathrm{g} / \mathrm{L}$} & \multicolumn{2}{|c|}{$\operatorname{TgAb}, \mathrm{U} / \mathrm{mL}$} & \multirow[t]{2}{*}{ Recovery, \% } \\
\hline & & & & & Immulite & Kryptor & Immulite & Kryptor & \\
\hline 1 & Female & 41.8 & FTC & Bone & 0.0 & 0.0 & 0.0 & 19.0 & 101 \\
\hline 2 & Female & 72.3 & PTC & Lung & 0.0 & 0.3 & 0.0 & 13.0 & 92 \\
\hline 3 & Female & 68.8 & PTC & Lung, liver & 0.0 & 0.3 & 3.5 & 15.0 & 122 \\
\hline 4 & Male & 23.7 & PTC & Lung & 0.0 & 0.0 & $>3,000.0$ & $33,950.0$ & 75 \\
\hline 5 & Female & 51.3 & $\mathrm{HCC}$ & Neck & 0.0 & 0.2 & 0.0 & 16.0 & 104 \\
\hline 6 & Male & 69.3 & PTC & Neck & 0.0 & 0.1 & 0.0 & 0.0 & 94 \\
\hline 7 & Male & 73.7 & PTC & Neck & 0.0 & 0.5 & 0.0 & 0.0 & 105 \\
\hline 8 & Female & 67.1 & PTC & Neck & 0.0 & 0.4 & 0.0 & 0.0 & 104 \\
\hline 9 & Male & 54.0 & PTC & Neck & 0.0 & 0.2 & 0.0 & 0.0 & 125 \\
\hline 10 & Female & 66.6 & PTC & Neck & 0.0 & 0.5 & 0.1 & 11.0 & 100 \\
\hline 11 & Female & 50.3 & PTC & Neck & 0.0 & 0.2 & 0.6 & 11.0 & 104 \\
\hline 12 & Female & 57.6 & PTC & Neck & 0.0 & 0.2 & 1.3 & 0.0 & 105 \\
\hline 13 & Female & 48.2 & PTC & Neck & 0.0 & 0.2 & 1.8 & 0.0 & 94 \\
\hline 14 & Female & 40.7 & PTC & Neck & 0.0 & 1.4 & 17.7 & 122.0 & 96 \\
\hline 15 & Female & 41.7 & PTC & Neck & 0.0 & 0.0 & 63.5 & 21.2 & 88 \\
\hline
\end{tabular}

Tg, thyroglobulin; TgAb, Tg antibodies; PTC, papillary thyroid cancer.

fixed cut-offs, a substantial proportion of DTC patients are classified differently dependent on which Tg assay is used. This implies that clinical management of these patients can differ dependent on which assay is used.

International guidelines advocate the use of both Tgon and rh-TSH-Tg measurements for determining the response to therapy throughout follow-up in patients who have initially been treated with thyroidectomy and RAI ablation. Patients are stratified as having an excellent, indeterminate or incomplete response based on fixed $\mathrm{Tg}$ cut-offs $[8,9]$. The guideline cut-offs for Tg are based on studies measuring $\mathrm{Tg}$ with a variety of methods, mostly with a FS of $1.0 \mu \mathrm{g} / \mathrm{L}$ [10-14]. Although between-method differences for $\mathrm{Tg}$ measurement have been clearly recognized, these differences were not addressed in the studies providing the guideline cut-offs [2]. Discrepancies between
Tg assays relate, amongst others, to specificity differences in the antibody reagents of the assay, heterogeneity in tumor derived $\mathrm{Tg}$ and interference of $\operatorname{TgAb}[2,16,17]$. Even after standardization against the same reference standard a two-fold between-method difference in Tg concentrations has been reported $[2,3]$. Despite these differences, international guidelines propose fixed cut-offs [8, 9].

When applying the most clinically relevant Tg cut-off of $1.0 \mu \mathrm{g} / \mathrm{L}$, discrepancy in staging was observed between the Immulite and Kryptor assays in $6.0 \%$ and $4.3 \%$ of patients for Tg-on and rh-TSH-Tg, respectively. Disagreement on response to therapy was observed in $16.2 \%$ of patients. The observed discordance on response to therapy classification is caused by between-method slope bias, differences in FS and disagreement on TgAb positivity. The analytical bias, which can be positive or negative, may add to 
decreased concordance between-methods as demonstrated in a study of Ross et al. [18] The analytical bias for the studied assays was assessed, and was $35 \%$, with Immulite generating higher results. The negative analytical bias for the Kryptor assay was in line with previously published data from our group [19]. Due to the lower FS of Kryptor $(0.15 \mu \mathrm{g} / \mathrm{L}$ compared to $0.9 \mu \mathrm{g} / \mathrm{L}$ for Immulite $)$ more patients will be classified as having an indeterminate response with Kryptor, at the cost of the number of patients with an excellent response. In 39 of these patients an Immulite rh-TSH-Tg was performed before the study period, but a Kryptor rh-TSH-Tg measurement was not available. Based on the institutionally established performance of Kryptor Tg-on as a predictor of Kryptor rh-TSH-Tg (positive predictive value of $68 \%$, see Supplementary Figure S2), one would expect that $32 \%$ of these patients will have a Kryptor rh-TSH-Tg below the cut-off of $1.0 \mu \mathrm{g} / \mathrm{L}$. This implicates that, if a Kryptor rh-TSH-Tg would have been performed, an estimated number of 12 of these 39 patients would have remained in the excellent response category instead of being reclassified from excellent to indeterminate response. Therefore, even after correction for the missing Kryptor rh-TSH-Tg measurements, the use of the Kryptor assay will result in a larger proportion of patients with an indeterminate response to therapy classification. These patients will be exposed to more intensive follow-up, longer TSH suppressive therapy and additional therapies.

The clinical significance of detectable $\mathrm{Tg}$ levels in the low range $(0.2-1.0 \mu \mathrm{g} / \mathrm{L})$ is not clear. The origin might be thyroid remnant, (irradiated) tumor tissue or reflect microscopic tumor foci that will eventually result in clinically apparent disease recurrence. To minimize Tg produced by thyroid remnant, measurements taken in the first six months after the first RAI ablation were excluded from the analysis. Assays with lower FS have been reported to have higher sensitivity for predicting recurrent disease compared to assays with higher FS although it is unclear if long term outcomes are influenced [3, 20, 21]. However, the increased sensitivity of these assays is at the cost of specificity. Multiple studies have shown that measurable $\mathrm{Tg}$ levels up to $1.0 \mu \mathrm{g} / \mathrm{L}$ spontaneously convert into undetectable $\mathrm{Tg}$ in the majority of patients without further treatment, including in patients with high risk for recurrence [22-26]. Castagna et al. showed that only rh-TSH-Tg measurements could distinguish patients with persistent or biochemical disease from patients free of disease but others have argued that hs-Tg assays can replace rhTSH-Tg measurements [27, 28]. In our cohort 3 out of 70 rhTSH-Tg measurements showed discrepancy between the assays when the cut-off of $1.0 \mu \mathrm{g} / \mathrm{L}$ was applied. The comparability between $\mathrm{Tg}$ measurements is also compromised by interfering TgAb. Immunoassays are not able to detect TgAb-bound Tg which may result in underestimation of Tg concentrations [29-31]. In our cohort, $\mathrm{Tg}$ concentrations were significantly lower in $\mathrm{TgAb}+$ samples compared to $\operatorname{TgAb}$ - samples. As the presence of $\operatorname{TgAb}$ is associated with a higher risk of recurrence, guidelines recommend to measure $\mathrm{TgAb}$ simultaneously with $\mathrm{Tg}$ and monitor $\mathrm{TgAb}+$ patients more frequently.

In this study, disagreement on $\mathrm{TgAb}$ positivity between the assays was observed in $11.4 \%$ of patients. In these patients $\mathrm{Tg}$ would be judged as a reliable marker with one assay, but not with the other, which has an obvious impact on the follow-up strategy. TgAb+ patients have often been excluded in the studies providing the cut-offs for Tg concentration included in guidelines [10-12, 14]. As determination of $\operatorname{TgAb}$ positivity is TgAb assay-dependent, patients with present but undetectable $\mathrm{TgAb}$ with the specific assays used, have possibly been included in these analyses, potentially influencing the established cut-off for $\operatorname{Tg}$ [32].

Between-method discordance for $\mathrm{TgAb}$ measurement is caused by heterogeneity of endogenous TgAb, differences in sensitivity of the TgAb method and the (arbitrary) selected cut-off for TgAb positivity [7, 30, 33]. If liquid chromatography-tandem mass spectrometry (LC-MS/MS), which is considered not to be influenced by interfering $\mathrm{TgAb}$, is used as a reference, four tested TgAb immunoassays (including Immulite) missed $16-54 \%$ of interfering $\mathrm{TgAb}$ [31]. In addition, the concentration of $\mathrm{TgAb}$ is not linearly associated with interference and undetectable TgAb does not rule out interference [30, 31, 34]. The clinical impact of interfering antibodies remains unclear. A recent study showed that in patients with evidence of structural disease, $\operatorname{TgAb}$ interference rarely resulted in undetectable $\mathrm{Tg}$ levels [35]. However, low volume recurrent disease can potentially be missed. As Tg measurement with LCMS/MS does not suffer from TgAb interference, this method is a promising candidate for reliable $\mathrm{Tg}$ measurements. Currently, the inferior FS compared to immunoassays and time consuming procedures hinder implementation of LC-MS/MS in clinical care [28].

$\mathrm{TgAb}$ interference can also be qualitatively investigated with a recovery method. In our study a recovery test was performed on the Kryptor platform. Median recovery values were significantly lower in $\mathrm{TgAb}+$ samples. However, also in measurements with a normal recovery value according to the manufacturers' cut-off, median Tg concentration were lower in $\mathrm{TgAb}+$ measurements. This suggests that a normal recovery does not rule out $\mathrm{TgAb}$ interference. When applying the cut-off for disturbed recovery $(<80 \%)$, only $2.6 \%$ of samples were identified as 
such. In $5.5 \%$ of measurements recovery was $>120 \%$, most likely caused by interfering heterophilic antibodies (HAbs), which have a reported prevalence of 1.5-3\% [36].

Recovery values were investigated in the subcategory of patients with structural disease and undetectable $\mathrm{Tg}$ with one or both assays (assuming false negative results due to $\operatorname{TgAb}$ interference in at least a proportion of patients). Only one out of 15 samples showed a recovery $<80 \%$ and a very high concentration of $\operatorname{TgAb}(>3,000 \mathrm{U} / \mathrm{mL})$ was detected in that specific sample. Although Immulite failed to detect Tg in all these patients, Kryptor Tg was detectable in 12 out of 15 patients. This illustrates the increased diagnostic accuracy of a high-sensitive assay and that a recovery test does not aid in the discrimination of patients with unreliable $\mathrm{Tg}$ concentrations due to $\mathrm{TgAb}$ interference. Our study confirmed previous studies reporting a limited value of recovery measurement in determining $\mathrm{TgAb}$ interference $[17,35,37]$ and is in agreement with current guidelines advocating against the use of the recovery method $[4,8,38]$.

The results of this study show that comparability between $\mathrm{Tg}$ and $\mathrm{TgAb}$ assays is affected by the use of fixed cut-offs, which may be ameliorated by the application of assay-specific cut-offs. Trimboli et al. showed that assayspecific cut-offs increases comparability in clinical performance [39]. According to a study of Giovanella et al. these cut-offs should be further tailored based on TgAb status. Lower Tg cut-offs should be applied in $\mathrm{TgAb}+$ patients compared to TgAb- patients [40].

Our study has its strengths and limitations. The strength of this study is the simultaneous measurement of $\mathrm{Tg}$ and $\mathrm{TgAb}$ with two distinct assays in a large cohort of DTC patients. As all samples were measured directly after the blood was drawn from patients, bias due to freeze-thaw cycles or storage was prevented. Assays were not only compared mutually, but the impact on response to therapy classification was also investigated, contributing to assessing the clinical relevance of the between-method variations observed. We would like to mention a number of limitations. First, although the percentage of patients with positive $\mathrm{TgAb}$ and with disease recurrence was as expected and in line with the literature, the total numbers of these patients where relatively small. Second, different methods were used for establishing the cut-off for TgAb positivity for the included TgAb assays. Originally, TgAb were used as a marker for thyroid auto-immunity and the reference values were aimed at distinguishing patients with and without thyroid auto-immunity with adequate specificity [41]. At the time of introduction of the Immulite TgAb assay into our hospital, only the upper reference limit based on detecting auto-immunity was provided by the manufacturer. With the increasing use of Tg as a follow-up marker in DTC patients, it became clear that any level of TgAb can potentially interfere with $\mathrm{Tg}$ measurement. Therefore, an institutionally determined upper reference limit for the Immulite $\mathrm{TgAb}$ assay was used in the follow-up of DTC patients in our hospital. This cut-off was based on the level at which clinically relevant interference of $\mathrm{Tg}$ measurement was observed. For the Kryptor TgAb assay the functional sensitivity of the assay was used as the cut-off, in line with recommendations in current guidelines [4]. Evolving insights into the appropriate cut-off for $\operatorname{TgAb}$ positivity limits a full comparison of the studied assays. However, our study represents real-life observational data which may be relevant for daily clinical practice. Third, we only compared two assays, limiting the applicability to other $\mathrm{Tg} / \mathrm{TgAb}$ assays.

Our study indicates that classification and management of a substantial subset of DTC patients is affected, dependent on which Tg and TgAb assays are used, should fixed Tg cut-offs be applied. Therefore, the recommended Tg cut-offs in guidelines should be used with wisdom rather than as fixed cut-offs.

Research funding: None declared.

Author contributions: All authors have accepted responsibility for the entire content of this manuscript and approved its submission.

Competing interests: Authors state no conflict of interest. Informed consent: A waiver for informed consent was obtained due to the retrospective character of the study.

Ethical approval: This study was approved by the medical Ethical Board of the Erasmus University Medical Center (MEC-2018-1195).

\section{References}

1. Pacini F, Molinaro E, Castagna MG, Agate L, Elisei R, Ceccarelli C, et al. Recombinant human thyrotropin-stimulated serum thyroglobulin combined with neck ultrasonography has the highest sensitivity in monitoring differentiated thyroid carcinoma. J Clin Endocrinol Metab 2003;88:3668-73.

2. Spencer CA, Bergoglio LM, Kazarosyan M, Fatemi S, LoPresti JS. Clinical impact of thyroglobulin (Tg) and Tg autoantibody method differences on the management of patients with differentiated thyroid carcinomas. J Clin Endocrinol Metab 2005;90:5566-75.

3. Schlumberger M, Hitzel A, Toubert ME, Corone C, Troalen F, Schlageter $\mathrm{MH}$, et al. Comparison of seven serum thyroglobulin assays in the follow-up of papillary and follicular thyroid cancer patients. J Clin Endocrinol Metab 2007;92:2487-95.

4. Baloch Z, Carayon P, Conte-Devolx B, Demers LM, FeldtRasmussen $\mathrm{U}$, Henry JF, et al. Laboratory medicine practice 
guidelines. Laboratory support for the diagnosis and monitoring of thyroid disease. Thyroid 2003;13:3-126.

5. Pickett AJ, Jones M, Evans C. Causes of discordance between thyroglobulin antibody assays. Ann Clin Biochem 2012;49: 463-7.

6. Nygaard B, Bentzen J, Laurberg P, Pedersen SM, Bastholt L, Handberg A, et al. Large discrepancy in the results of sensitive measurements of thyroglobulin antibodies in the follow-up on thyroid cancer: a diagnostic dilemma. Eur Thyroid J 2012;1:193-7.

7. Spencer C, Petrovic I, Fatemi S. Current thyroglobulin autoantibody (TgAb) assays often fail to detect interfering $\operatorname{TgAb}$ that can result in the reporting of falsely low/undetectable serum Tg IMA values for patients with differentiated thyroid cancer. J Clin Endocrinol Metab 2011;96:1283-91.

8. Haugen BR, Alexander EK, Bible KC, Doherty GM, Mandel SJ, Nikiforov YE, et al. 2015 American Thyroid Association management guidelines for adult patients with thyroid nodules and differentiated thyroid cancer: the American Thyroid Association Guidelines Task Force on thyroid nodules and differentiated thyroid cancer. Thyroid 2016;26:1-133.

9. Perros P, Boelaert K, Colley S, Evans C, Evans RM, Gerrard Ba G, et al. Guidelines for the management of thyroid cancer. Clin Endocrinol 2014;81(1 Suppl):1-122.

10. Tuttle RM, Tala H, Shah J, Leboeuf R, Ghossein R, Gonen M, et al. Estimating risk of recurrence in differentiated thyroid cancer after total thyroidectomy and radioactive iodine remnant ablation: using response to therapy variables to modify the initial risk estimates predicted by the new American Thyroid Association staging system. Thyroid 2010;20:1341-9.

11. Vaisman F, Tala H, Grewal R, Tuttle RM. In differentiated thyroid cancer, an incomplete structural response to therapy is associated with significantly worse clinical outcomes than only an incomplete thyroglobulin response. Thyroid 2011;21: 1317-22.

12. Vaisman F, Momesso D, Bulzico DA, Pessoa CH, Dias F, Corbo R, et al. Spontaneous remission in thyroid cancer patients after biochemical incomplete response to initial therapy. Clin Endocrinol 2012;77:132-8.

13. Jeon MJ, Kim WG, Park WR, Han JM, Kim TY, Song DE, et al. Modified dynamic risk stratification for predicting recurrence using the response to initial therapy in patients with differentiated thyroid carcinoma. Eur J Endocrinol 2014;170:23-30.

14. Castagna MG, Maino F, Cipri C, Belardini V, Theodoropoulou A, Cevenini $G$, et al. Delayed risk stratification, to include the response to initial treatment (surgery and radioiodine ablation), has better outcome predictivity in differentiated thyroid cancer patients. Eur J Endocrinol 2011;165:441-6.

15. D’Aurizio F, Metus P, Ferrari A, Caruso B, Castello R, Villalta D, et al. Definition of the upper reference limit for thyroglobulin antibodies according to the National Academy of Clinical Biochemistry guidelines: comparison of eleven different automated methods. Autoimmun Highlights 2017;8:8.

16. Schulz R, Bethäuser H, Stempka L, Heilig B, Moll A, Hüfner M. Evidence for immunological differences between circulating and thyroid tissue-derived thyroglobulin in men. Eur J Clin Invest 1989;19:459-63.

17. Spencer CA, Takeuchi M, Kazarosyan M. Current status and performance goals for serum thyroglobulin assays. Clin Chem 1996;42:164-73.
18. Ross HA, Netea-Maier RT, Schakenraad E, Bravenboer B, Hermus AR, Sweep FC. Assay bias may invalidate decision limits and affect comparability of serum thyroglobulin assay methods: an approach to reduce interpretation differences. Clin Chim Acta 2008;394:104-9.

19. Schoonen L, Neele M, van Toor H, van Kinschot CMJ, van Noord C, Visser E, et al. Impact of thyroglobulin and thyroglobulin antibody assay performance on the differential classification of DTC patients. J Endocr Soc 2022;6:1-10.

20. Smallridge RC, Meek SE, Morgan MA, Gates GS, Fox TP, Grebe S, et al. Monitoring thyroglobulin in a sensitive immunoassay has comparable sensitivity to recombinant human tsh-stimulated thyroglobulin in follow-up of thyroid cancer patients. I Clin Endocrinol Metab 2007;92:82-7.

21. Zöphel K, Wunderlich G, Smith BR. Serum thyroglobulin measurements with a high sensitivity enzyme-linked immunosorbent assay: is there a clinical benefit in patients with differentiated thyroid carcinoma? Thyroid 2003;13:861-5.

22. Kloos RT, Mazzaferri EL. A single recombinant human thyrotropinstimulated serum thyroglobulin measurement predicts differentiated thyroid carcinoma metastases three to five years later. J Clin Endocrinol Metab 2005;90:5047-57.

23. Kloos RT. Thyroid cancer recurrence in patients clinically free of disease with undetectable or very low serum thyroglobulin values. J Clin Endocrinol Metab 2010;95:5241-8.

24. Baudin E, Do Cao C, Cailleux AF, Leboulleux S, Travagli JP, Schlumberger M. Positive predictive value of serum thyroglobulin levels, measured during the first year of follow-up after thyroid hormone withdrawal, in thyroid cancer patients. J Clin Endocrinol Metab 2003;88:1107-11.

25. Torlontano M, Attard M, Crocetti U, Tumino S, Bruno R, Costante G, et al. Follow-up of low risk patients with papillary thyroid cancer: role of neck ultrasonography in detecting lymph node metastases. J Clin Endocrinol Metab 2004;89:3402-7.

26. Giovanella L, Maffioli M, Ceriani L, De Palma D, Spriano G. Unstimulated high sensitive thyroglobulin measurement predicts outcome of differentiated thyroid carcinoma. Clin Chem Lab Med 2009;47:1001-4.

27. Malandrino P, Latina A, Marescalco S, Spadaro A, Regalbuto C, Fulco RA, et al. Risk-adapted management of differentiated thyroid cancer assessed by a sensitive measurement of basal serum thyroglobulin. J Clin Endocrinol Metab 2011;96:1703-9.

28. Castagna MG, Tala Jury HP, Cipri C, Belardini V, Fioravanti C, Pasqui $\mathrm{L}$, et al. The use of ultrasensitive thyroglobulin assays reduces but does not abolish the need for TSH stimulation in patients with differentiated thyroid carcinoma. J Endocrinol Invest 2011;34:e219-23.

29. Spencer CA. Challenges of serum thyroglobulin (Tg) measurement in the presence of $\mathrm{Tg}$ autoantibodies. J Clin Endocrinol Metab 2004;89:3702-4.

30. Spencer CA, Takeuchi M, Kazarosyan M, Wang CC, Guttler RB, Singer PA, et al. Serum thyroglobulin autoantibodies: prevalence, influence on serum thyroglobulin measurement, and prognostic significance in patients with differentiated thyroid carcinoma. J Clin Endocrinol Metab 1998;83:1121-7.

31. Netzel BC, Grebe SK, Carranza Leon BG, Castro MR, Clark PM, Hoofnagle AN, et al. Thyroglobulin (Tg) testing revisited: $\mathrm{Tg}$ assays, TgAb assays, and correlation of results with clinical outcomes. J Clin Endocrinol Metab 2015;100:E1074-83. 
32. Krahn J, Dembinski T. Thyroglobulin and anti-thyroglobulin assays in thyroid cancer monitoring. Clin Biochem 2009;42: 416-9.

33. Spencer C, Petrovic I, Fatemi S, LoPresti J. Serum thyroglobulin (Tg) monitoring of patients with differentiated thyroid cancer using sensitive (second-generation) immunometric assays can be disrupted by false-negative and false-positive serum thyroglobulin autoantibody misclassifications. J Clin Endocrinol Metab 2014;99:4589-99.

34. Clark PM. Laboratory services for thyroglobulin and implications for monitoring of differentiated thyroid cancer. J Clin Pathol 2009; 62:402-6.

35. Giovanella L, Verburg FA, Trimboli P, Imperiali M, Keller F, Ceriani L. Measuring thyroglobulin in patients with thyroglobulin autoantibodies: evaluation of the clinical impact of BRAHMS Kryptor(R) Tg-minirecovery test in a large series of patients with differentiated thyroid carcinoma. Clin Chem Lab Med 2019;57: 1185-91.

36. Preissner CM, O’Kane DJ, Singh RJ, Morris JC, Grebe SK. Phantoms in the assay tube: heterophile antibody interferences in serum thyroglobulin assays. J Clin Endocrinol Metab 2003;88:3069-74.

37. Massart C, Maugendre D. Importance of the detection method for thyroglobulin antibodies for the validity of thyroglobulin measurements in sera from patients with Graves disease. Clin Chem 2002;48:102-7.

38. Verburg FA, Luster M, Cupini C, Chiovato L, Duntas L, Elisei R, et al. Implications of thyroglobulin antibody positivity in patients with differentiated thyroid cancer: a clinical position statement. Thyroid 2013;23:1211-25.

39. Trimboli P, Imperiali M, Piccardo A, Campennì A, Giordani I, Ruggeri RM, et al. Multicentre clinical evaluation of the new highly sensitive Elecsys ${ }^{\circledR}$ thyroglobulin II assay in patients with differentiated thyroid carcinoma. Clin Endocrinol 2018;88: 295-302.

40. Giovanella L, Imperiali M, Verburg FA, Trimboli P. Early posttreatment risk stratification of differentiated thyroid cancer: comparison of three high-sensitive Tg assays. Eur J Endocrinol 2018;178:75-82.

41. Hollowell JG, Staehling NW, Flanders WD, Hannon WH, Gunter EW, Spencer CA, et al. Serum TSH, T(4), and thyroid antibodies in the United States population (1988 to 1994): National Health and Nutrition Examination Survey (NHANES III). J Clin Endocrinol Metab 2002;87:489-99.

Supplementary Material: The online version of this article offers supplementary material (https://doi.org/10.1515/cclm-2021-1046). 